\title{
Impact of Airline Mobile Applications on Passenger Satisfaction in Egyptair
}

\author{
Hussein Abdel Wahab Abdel Rady \\ Lecturer, Tourism Studies Department \\ Faculty of Tourism and Hotels - Minia University
}

\begin{abstract}
The progress of Information Technology (IT) has altered the business sector in various industries in general and in the airline sector in particular. Modern Information and Communication Technologies (ICTs) provides strong instruments for institutions and can seriously impact their operation, structure, and method. The advent of mobile technologies has provided modern innovation for airlines by increasing the availability, frequency, and speed of interaction between the airlines and its passengers.
\end{abstract}

This paper aims to investigate the status quo and potential of mobile services in the airline sector. Mobile airline services, such as booking, check-in, boarding pass, gate caller, flight and lost baggage information, have been increasingly utilized recently, and this paper aims to analyze the effects of mobile marketing tool at passenger satisfaction of Egyptair. To achieve that, this research employed a method of descriptive analytical methodology by using a questionnaire tool. The sample was passengers in Egyptair. 400 questionnaires were administered; only (384) returned questionnaires were valid for the statistical manipulation of data with a response rate of $96 \%$ from the total distributed questionnaires in Cairo international airport and Egyptair domestic sales offices. The results of the tools were analyzed using descriptive statistics, reliability analysis, coefficient analysis, spearman correlation analysis, and regression analysis. With the support of SPSS18.0.

The research reached several results, the most important of which is the presence of the application is very flexible. Airline mobile applications are the best way of airline service because of its ease of use and availability when needed; there is positive significant relationship between passenger satisfaction and using of airline mobile application. The research thus recommended that Egyptair should develop mobile applications to offer airline service. They should announce their mobile application in their website, social media. They should make training for their staff in mobile applications using. Developing mobile applications include several features that increase the number of passengers and attract others to use it.

KEYWORDS: Mobile Applications, Airline Mobile Applications, Mobile Marketing, Passenger Satisfaction, Egyptair.

\section{Introduction}

Mobile technology is changing the movement encounter. A cell phone has turned into a standard embellishment for all passengers. Passengers depend on versatile innovation for 
moment data and associations with their interpersonal organization. Carriers keep on acquainting versatile capacities with enhancing passengers preparing and data stream. All around an arrangement of standard capacities have developed for carrier portable applications. The airlines are starting to structure their own airline mobile application or have other companies develop the airline mobile applications for them. A typical airline application would incorporate the capacity for passengers to buy a flight, to registration early, or acquire their tickets from the mobile booths at the airports. However, as the competition increases between the airlines and between third-party airlines mobile application developers, some airline applications have added features that could support with airport navigation (Amadeus, 2011). In order to develop an edge over competitors, airline operators, in general, need to make a feasible upper hand dependent on expanded operational viability and satisfactory key situating. Whenever coordinated legitimately into the esteem chain, a "mobile" innovation plan of action can expand an aircraft's working proficiency and passenger satisfaction by encouraging business forms, giving passengers esteem included administrations and by making collaborations between carriers' center capabilities and portable innovation (Ekelhart \&Manhoot, 2008).

Smart mobility-based operations can change systematic value decrease by simplifying the airline, airport, and passenger value chain. In this way, the industry should recognize immediate value impact on airline/airport operations and passenger services, and the ability to monitor, manage, and control existing and new operational metrics (Howard et al., 2010). With a mobile application of Egyptair, passengers can manage several flight-related services through their mobile devices terribly simply. With a mobile application of Egyptair, which is offered free from charge, passengers will arrange their domestic and international flights and purchase tickets. It is also doable to visualize in check in using the mobile application and to receive mobile barcode through e-mail and short message service (SMS). Thus, passengers can board the plane by simply scanning a barcode if the passenger has no checked baggage. With this application, the passenger will purchase any seat passenger needs, and passenger will purchase the menu passenger needs beforehand. What is more, the passenger will demand to be served first. In the application through which departure and arrival times are often followed, payments are secured.

\section{Research Problem}

With the expanded market competition, Egyptair don't appear to be prepared to just and expediently adjust and conform to changes in markets and in addition to gain a competitive advantage. To do this, Egyptair should connect airline mobile applications and Egyptair performance with the general objectives of airlines. This is accomplished by measuring the performance of Egyptair mobile application and passengers where airline should decide the foremost appropriate tool or framework that expands the Egyptair performance. The primary issue of this research is: "Does mobile applications affect Egyptair performance"?

\section{Research Questions}

Based on the necessity to offer services that attract passengers to utilize mobile applications and desirous to connect on a private level with the passengers, there is a require research into the attainable effects on the passenger relationship. The research question so is: To 
what extent will the airline mobile applications have an effect on passenger behaviour and however does it contribute to the passenger satisfaction towards the airline?

\section{The research question will be split into}

\section{three sub questions:}

SQ1: At what point in the innovation-process are the passenger and do they use airline mobile applications for travel functions already?

SQ2: How does the introduction of airline mobile applications affect passenger's behavior? SQ3: Is airline mobile application an appropriate tool to increase passenger satisfaction towards an airline?

\section{Research Aims}

This research aims to investigate the present status and capability of mobile services in airlines. airline mobile services, for example, booking, check-in, boarding pass, gate caller, flight information and lost luggage information, have been progressively utilized in the airlines of the most recent years, and this research is focused on analyzing the fundamental ideas about airline mobile marketing and mobile applications, and evaluating the effect of mobile application in the levels of passengers satisfaction and enhancement of the image/ impression of Egyptair mobile applications. Moreover, the Research is verified by achieving the following objectives:

1. Identify the importance of the using the mobile applications in offering and marketing of Egypt air's airline services.

2. Exploring the current situation of the using of mobile applications in Egyptair.

3. Developing a mobile airline seat reservation system that will assist the general public in gaining better and quicker tool for seat reservation and providing them with more options to book a ticket for traveling on real time.

\section{Research Significance}

Mobile technology is quickly getting to be indispensable to airline operations and the passenger encounter. The utilization of mobile advancements by everyone prompts inventive marketing applications in air travel and reshapes the air travel involvement. Besides, portable advertising applications are starting to assume a critical job in the accomplishment of worldwide airlines. Passengers are progressively utilizing their advanced mobile phones and tablets to book tickets and save seats. Numerous passengers are likewise utilizing their cell phones for self-service check-in, seating assignments and things following, and for continuous data on flight entry and takeoff times and climate and movement conditions. Airlines are additionally taking a gander at portable stages to give passenger marketing of airline and air terminal subordinate administrations. The economic recessions in recent years have led to costefficient policies in the aviation industry, Mobile marketing applications changing into more and more vital important for airline businesses each to confirm operational efficiency and passenger satisfaction and additionally to conduct their interactive marketing activities in a cost- efficient way. The research and projections carried out by Society International Telecommunication For Aeronautics (SITA) and Amadeus on airline mobile marketing activities indicate that airline companies are continuing to invest in such marketing and airline passengers are interested in these types of activities that facilitate their travel experiences, Hence the importance of research to demonstrate the current status and potential of mobile services 
in Egyptair, and this research seeks to analyze the effects of airline mobile applications at passenger satisfaction in Egyptair.

\section{Literature Review}

\subsection{Information and Communication Technologies (ICTs) in Airline}

The rapid development of the mobile device (smartphone) creates a new tool in mobile market that's mobile apps (Kennedy-Eden \& Gretzel, 2012). Mobile applications in this time are a major growth sector of the information and communications economy. (Delhumeau, 2013). In the airline industry, a number of tasks and functions various undertakings and capacities, for example, task administrations, in-flight stimulation, and passenger benefit, rely upon data correspondence advancements Information and Communication Technologies. Thus, data correspondence innovations Information and Communication Technologies are utilized vigorously via aircrafts and a lot of capital has been put resources into this field (Buhalis, 2004). It is argued that a variety of industries are probably to be considerably modified by the emerging of mobile technologies, and this technology will force companies to measure their methods (Barnes, 2003). According to Scharl et al., (2005), Mobile devices have increased the accessibility, frequency, and speed of communication between passengers and corporations. So, a new prospect has been created, via mobile gadgets, to provide new services for existing and potential passengers (Lubbe \& Louw, 2010). Moreover, Kim et al., (2005) suggested that mobile commerce ought to be seen by airline companies as a new and additional interactive technique of doing business. Further, smartphone's and tablets make passengers detached from their desktop laptop and offer them anyplace and anytime access, also the technology of mobile has impacted all stages of the travel life cycle figure (1) and offers the chance for continuous engagement (Amadeus, 2011).

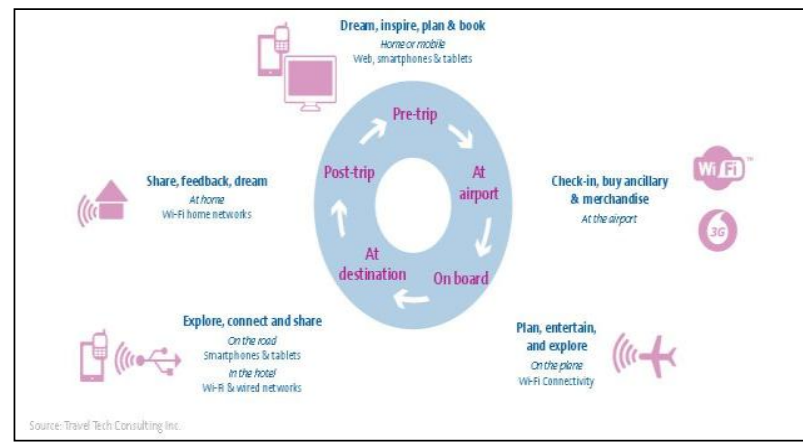

Figure (1) Mobile's impact across the travel lifecycle. Source: (Amadeus, 2011).

\subsection{Definition of Mobile Applications}

Mobile applications are applications that are intended to keep running on cell phones and different gadgets that have mobile ability. They are planned so that any telephone that has the application highlights can utilize them without influencing ordinary operations of the telephone itself. With the dimension of innovation on the planet today, programming applications to peruse the web, reserve lodgings, car rental, booking seat on an aircraft and so on., can be introduced on cell phone consequently bringing most extreme usage of time and all other human resources to their adequate dimension of life (Alo et al., 2014).

\subsection{Mobile Marketing}

Mobile marketing is flourishing in a field of recent technologies that is subject to continuous amendment (Florido-Benítez, Del Alcázar, \& González, 2014). This has led to it being defined in numerous ways in which numerous interpretations. Alkaya (2007) precisely defines it as, "Mobile marketing or wireless marketing is generally utilizing instant messages through cell phones in marketing communication". As indicated by 
another definition, mobile marketing showcasing can be characterized as the exercises to advance administrations and thoughts through cell phones, setting up advertising contact with the objective customers and sending them advancement situated messages with the end goal to benefit all the intrigue gatherings of a specific business (Barutçu \& Öztürk, 2009). Mobile marketing began with the integration of mobility into other marketing media. In such promotions, Mobility applications are used as a tool to interact with customers (Karaca \& Gülmez, 2010). However, (Dickinger, Haghiran, Murphy \& Scharl, 2004; Norm, 2011) view this marketing modality as a sales outlet for offering products and services to users. In the digital economy, companies create wealth by collection and applying knowledge (Sigala, 2001). According to (Hermoso de Mendoza, 2004; Martín de Bernardo \& Priede, 2007; Melendo, 2010; Kaplan, 2012) view mobile marketing as a tool in this activity, where they will develop their own designs, advertising and marketing campaigns, Nonetheless, authors like (Vlachos \& Vrechopoulos, 2007; Mobile Marketing Association, 2009; Shankar \& Balasubramanian, 2009) argue that this instrument is a means of communication that allows businesses to communicate with their customers interactively; exactly, for Shankar and Balasubramanian (2009), it is a bidirectional or multi-directional channel of communication between companies advertising deals and customers employing a mobile medium, device or technology.

\subsection{Airline Mobile Applications}

Airlines provide a range of mobile applications and tools providing a diversity of functionalities on the travel process. Table 1 below provides summary of passenger-focused mobile applications currently by Egyptair. These applications can be classified as information focused or process focused. The lion's share of uses is data centered, which can be either broad or flight explicit. General data centered applications run from giving climate and contact data, airport maps, and locating airport lounges. View schedules, itineraries and flight status updates. In contrast, process orienting applications focus on mobilizing existing business processes such as changing reservations, purchasing tickets, or checking-in for a flight (Pagiavlas et al., 2005).

Table (1) Airline Mobile Applications Overview

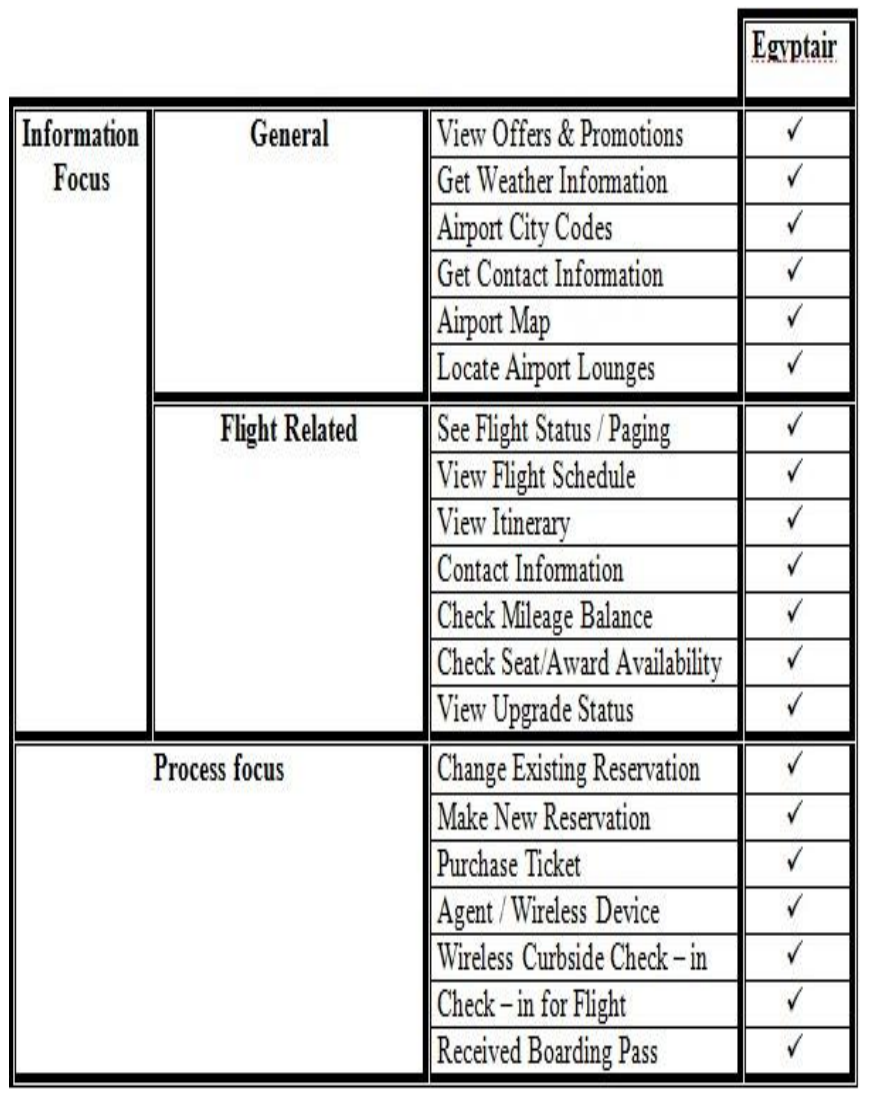

Source: Adopted by the Author based on Pagiavlas et al., (2005) Mobile Business - Comprehensive Marketing Strategies or Merely it expenses? A Case Study of the US Airline Industry.

\subsection{Mobile Applications Categories}

There are totally different taxonomies for mobile applications. Some researchers have categorized them as technical Approach and others as service 
supplier. Budiu (2013) posited that There are three main types of mobile apps from technical method as; (a) Native Mobile Apps, (b) Web Mobile Apps, (c) Hybrid Mobile Apps. Moreover, Kennedy and Gretzel (2012) suggested that there are seven categories for travel mobile applications from value chain. These categories are: Navigation, Social, Mobile Marketing, Security/ Emergency, Transactional, Entertainment, and Information Applications.

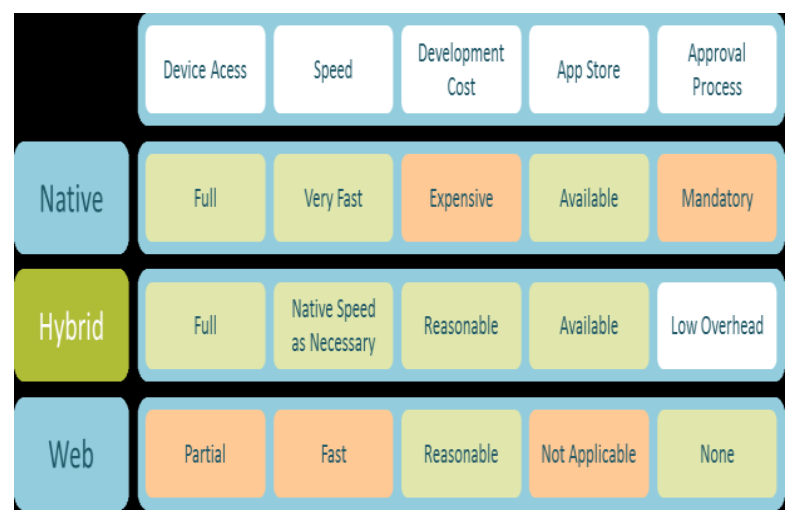

Fig (2) Mobile Applications Categories. Source: (NIIT Technologies, 2018)

The airline industry needs to pick between the three mobile applications dependent on various parameters, for example, budget, time allotment, inside assets, eventual fate of the market, required application usefulness and the developing needs of the passenger. In picking the stage to be utilized, numerous airlines confront a tradeoff between passengers experience from one perspective, and cost and time-to- market on the other.

\subsection{Impact Airline Mobile Applications on Passenger Satisfaction}

Mobile phones can impact the air travel expertise in six ways: keeping passengers informed by notifying them with any flight changes; mobile self-service applications can provide passengers greater control throughout their journey; creating travel paperless; facultative m-payment; marketers are ready to send targeted content to passengers' mobile devices; and passengers will progressively use mobile devices to make their own personal recreation system to be used on board by downloading contents from the web before their flight (Society International Telecommunication For Aeronautics (SITA), 2009).

\subsection{Developing Airline Mobile Applications}

Across the globe mobile technology is changing the eventual fate of air travel. Airlines not just need to keep pace with passenger expectations, yet additionally augment the one of a kind chance to utilize mobile technology for item separation, gradual deals and expanded brand loyalty. The following 10 years guarantees to be a wild ride, yet for those airlines who grab the chance, mobile technology can give a more proficient, cozy and productive association with passengers.

Table (2) Developing Airline Mobile Applications

\begin{tabular}{|c|c|c|}
\hline & $\begin{array}{l}\text { Available now or within } \\
12 \text { months }\end{array}$ & $\begin{array}{l}\text { Widespread 1-2 } \\
\text { years }\end{array}$ \\
\hline \multirow{6}{*}{$\begin{array}{l}\text { Mobile } \\
\text { Functionality }\end{array}$} & Booking & Immediate Social \\
\hline & Schedules & Media Response \\
\hline & Flight Status & \multirow[t]{2}{*}{ Book Loyalty } \\
\hline & Itinerary Management & \\
\hline & Seat Maps & \multirow[t]{2}{*}{ Enroll in Loyalty } \\
\hline & Check Loyalty Balance & \\
\hline \multirow{3}{*}{ Airport } & $\begin{array}{l}\text { Mobile Check-in and Bar- } \\
\text { Coded Boarding Pass (BCBP) }\end{array}$ & $\begin{array}{l}\text { Mobile Roaming } \\
\text { Agent }\end{array}$ \\
\hline & \begin{tabular}{|l|} 
Airport Information \\
\end{tabular} & \begin{tabular}{|l} 
Passenger Tracking \\
\end{tabular} \\
\hline & $\begin{array}{l}\text { Short Message Service(SMS) } \\
\text { Disruption Management }\end{array}$ & \begin{tabular}{|l} 
Mobile Electronic \\
Airline Voucher
\end{tabular} \\
\hline \multirow{3}{*}{$\begin{array}{c}\text { Ancillary } \\
\text { Services and } \\
\text { Merchandising }\end{array}$} & \multirow[t]{3}{*}{ Deals \& Offers } & $\begin{array}{l}\text { Airport Coupon } \\
\text { Offers }\end{array}$ \\
\hline & & $\begin{array}{l}\text { Location Based } \\
\text { Offers }\end{array}$ \\
\hline & & Ancillary Services \\
\hline
\end{tabular}

Source: (Amadeus, 2011). 


\subsection{The Benefit for Mobile Application in Airline Industry}

The mobile airline application is changing passenger expertise, as passengers constantly depend on their cell phones to associate with various kinds of businesses. With innovative improvements on the steady ascent, it is nothing unexpected that even airlines use airlines applications to upgrade the passenger expertise (Howard, et al., 2010; Amadeus, 2011; Alo et al., 2014; NIIT Technologies, 2018).

\subsubsection{Benefit for Airlines}

- Airlines can deliver relevant content, for example destination details, number of passengers, trip duration, travel time etc., to passengers. The information is additionally passed on to the crew members alongside with the preferences, thereby improving overall staff productivity.

- Mobility has further enabled the airline by providing ways that inform passengers about regarding transport disruptions, assist in ordering booking parking lots, and suggest looking decisions based mostly on passenger purchase history and preferences.

- Airlines can generate new revenues by providing mobility-enabled personalized services such as sale of putrescible products, empty seats or overhead space through time period auctions.

\subsubsection{Benefit for Passengers}

- Passengers are more alright with mobile technology progressions than airports and airlines. The quick pace of innovation development is coordinated by passengers anxious to get the freshest and most recent innovation.
- Mobile applications enable passengers to investigate and complete their travel cycle at their very own convenience. They can check in, select seats, and get their mobile boarding passes. This is an extraordinary preferred standpoint, particularly to the individuals who are dependably in a surge and don't have gear to check in. It spares their time from long lines and augments their additional hours.

- Mobile applications increment selfservice action and enhance dependability, improve passengers expertise. By starting more mobile check-in and reducing kiosk deployment.

- Smart telephones enable passengers to ask for and procure helpful data. For instance, short informing administration has been widely received to scatter reports on flight designs and sporadic tasks in crisis circumstances.

\subsubsection{Benefit for Airline Staff}

- Airline staffs are a lot of snug with mobile technology progressions than airports and airlines.

- Airline staffs will focus on disabled or less technology-savvy passengers. Mobile technology also supports reduce informational questions about gates, departure times and airline policies.

\subsection{Egyptair Mobile Application}

The mobile application of Egyptair gives passengers the adaptability to oversee parts of their flight, offering a large number of the well-known highlights found on egyptair.com, including (Egyptair, 2017): 
- Mobile checking in and choosing or changing seats.

- Manage booking and Flight booking service (including flex price \& payment).

- Checking real-time flight status and timetable information.

- Egyptair plus loyalty program account login and information.

- Baggage information.

- First and Business class lounges information.

- Viewing passenger itinerary, requesting a meal, and booking ground transportation.

- Ancillary services to be booked through mobile applications such as hotel booking.

- Onboard services information

- Special services information\& Special offers available on any specific flight.

- Destination guide and gallery.

Egyptair mobile application for windows phones, BlackBerry Phones, IPad, IPod, and Apple IPhone with new facilities provided, that allows boarding passes to be saved on passbook application, regardless of the device type used figure 3 demonstrates a case of how mobile applications can convey important customized substance to passengers. This application is offered to passengers gratis. This application, which helps find modest and booked flights, guides passengers to the important flight organization, allows sorting flights by price, cabin class, airlines, departure and arrival time.

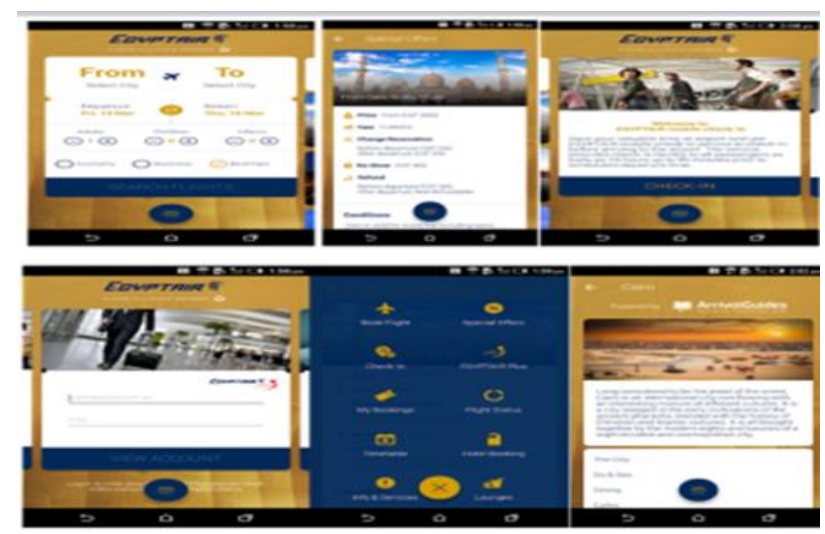

Figure (3) Booking Procedures in Egyptair Mobile Application. Source: (Egyptair application, 2018)

\section{Research Methodology}

The researcher used the descriptive analytical approach, where a questionnaire was prepared and distributed to a random sample of four hundred (400) of passengers in Egyptair. 384 $(96 \%)$ of passengers in Egyptair were retrieved. The statistical analysis of the responses was carried out via SPSS v18.

\subsection{Data Collection}

Data has been collected through questionnaires that were prepared in approach that is relevant to the situation so as to decrease invalid responses. They were distributed to passengers at Cairo international airport and Egyptair domestic sales offices.

\subsection{Measures}

To fulfill the research objective for identifying the current status and potential of mobile services in the airline business, airline mobile services, such as booking, check-in, boarding pass, gate caller, flight information and lost luggage information, have been increasingly used over the last years, and this paper seeks to analyze the effects of mobile marketing tool at passengers of Egyptair. To achieve that, this research employed a method of descriptive analytical methodology by using a questionnaire tool, a survey consisted of nine sections is used as a data collection tool. The first section includes the passengers' demographic characteristics (gender, age, and educational level). The second section includes travel and general characteristics (travel frequency, travel purpose, check-in method, and current use of mobile applications). The third section included 4 variables representing using of airline mobile applications. The fourth section functions of airline mobile application included 5 dimensions and 23 items (flights 3 items, booking 5 items, airport 3 items, airlines 4 items, and ancillary services on mobile devices 
7 items). The fifth section passenger requirements included 2 dimensions and 20 items (innovation features services 10 items and aspects of airline travel experience10 items). The sixth section included 3 variables representing cross-selling. The seventh section included 4 variables representing image perception. The eighth section included 4 variables representing passenger satisfaction. The ninth section included 6 variables representing security control. The questionnaire items were anchored according to the three point Likert Scale, "1 = Disagree", " 2 = Neutral", and "3 = Agree".

\subsection{Data Validity and Reliability Data Validity}

To validate the data collection instrument utilized in this study in terms of its readability, format, and ability to measure the study's constructs; the researcher distributed the questionnaire instrument to a number of passengers in Egyptair. The questionnaire instrument was then updated and refined to reflect the comments and suggestions received by the domain experts. Moreover, the experts showed interest and interacted with the researcher concerning the questionnaire instrument which adds to its validity.

\subsection{Data Reliability}

The reliability of an instrument is the degree of accuracy and consistency with that it measures whatever it is measuring (Ary et al., 2002). Before proceeding with further analysis, the reliability testing was leaded in order to ensure consistent measurement across various items in the questionnaire. Indeed, the reliability of a measure indicates stability and consistency of the instrument. Consequently, this method determines reliability through examining the internal consistency of the research instrument such as questions (items) in the questionnaire, which are normally presented. Cronbach's alpha coefficient measures this effect and ranges from 0 (no internal consistency) to 1 (maximum internal consistency) (Döckel, 2003). Reliability coefficient of 0.70 or higher is considered "acceptable" in most social science research situations (Nunnally, 1978). As depicted in table (3), the Cronbach's Alpha Reliability was computed for seven sections. The tests showed that the Reliability Coefficients for all the sections were equal 0.794 and Validity Coefficient for all the sections were equal 0.889 which indicates that the instrument is reliable for being used.

Table (3) Cronbach's Alpha Value for Airline Mobile Applications

\begin{tabular}{|l|c|c|c|}
\hline \multicolumn{1}{|c|}{ Variables } & $\begin{array}{c}\text { No. of } \\
\text { items }\end{array}$ & $\begin{array}{c}\text { Cronbach's } \\
\text { Alpha } \\
\text { Value }\end{array}$ & $\begin{array}{c}\text { Validity } \\
\text { Coefficient } \\
*\end{array}$ \\
\hline $\begin{array}{l}\text { Using of Mobile } \\
\text { Airline Applications }\end{array}$ & 4 & 0.828 & 0.909 \\
\hline $\begin{array}{l}\text { Functions of Mobile } \\
\text { Airline Application }\end{array}$ & 23 & 0.812 & 0.901 \\
\hline $\begin{array}{l}\text { Passenger } \\
\text { Requirements }\end{array}$ & 20 & 0.704 & 0.839 \\
\hline Cross Selling & 3 & 0.755 & 0.868 \\
\hline Image Perception & 4 & 0.731 & 0.854 \\
\hline $\begin{array}{l}\text { Passenger } \\
\text { Satisfaction }\end{array}$ & 4 & 0.979 & 0.989 \\
\hline Security Control & 6 & 0.749 & 0.865 \\
\hline Total & 64 & 0.794 & 0.889 \\
\hline
\end{tabular}

* Validity coefficient $=\sqrt{ }$ Reliability coefficient

In order to measure the internal consistency and reliability of the study's constructs. Cronbach's Alpha $(\alpha)$ measure was used. The scales' reliabilities were measured and the Cronbach's Alpha of all scales in Table (3) ranged from 0.704 to 0.979 , and for total questionnaire items was (0.794), this indicate an acceptable Cronbach's Alpha value for each field, whenever Cronbach's Alpha value is 
acceptable if it's more than (0.7). It is also evident that the validity coefficient is $(88.90 \%)$ which means the reliability and validity of the study sample.

\subsection{Data Analysis}

To achieve the objective of this study, the researcher used the descriptive analytical approach. The researcher depends on using The Statistical Package for Social Sciences (SPSS) was used to process data statistically. The treatment included the following statistical methods:

1. Frequencies, Percentages, Means, and Standard Deviation (SD): To describe the characteristics of the study population of the functional variables, and to determine the responses of its members towards the study axes.

2. Cronbach's Alpha Test: To calculate the stability coefficients of the questionnaire, and the coefficient of stability of each axis of the study axes.

3. Spearman Correlation analysis.

4. Regression analysis.

\section{Results and Discussion}

The following part explains the results concerning the nine dimensions representing of airline mobile applications delivered by Egyptair.

\subsection{Sample Characteristics}

The sample of the survey covered Egyptair which airline mobile applications are applied. A total of 400 questionnaires were distributed to passengers at Cairo international airport and Egyptair domestic sales offices. 384 (96\%) of respondents in Egyptair were retrieved.

\subsection{Descriptive analysis of airline mobile applications in Egyptair}

In this section, the researcher relied mainly on the descriptive analysis to get the means and the standard deviations for the study constructs along with their items. The items were measured using a Likert-type scale as follows.

\section{First Section: Demographic Characteristics of Respondents}

Table(4)the demographic profile of the sample elements

\begin{tabular}{|c|c|c|}
\hline Variable & Frequency & $\begin{array}{l}\text { Percentage } \\
(\%)\end{array}$ \\
\hline \multicolumn{3}{|l|}{ Gender } \\
\hline Male & 224 & 58.3 \\
\hline Female & 160 & 41.7 \\
\hline \multicolumn{3}{|l|}{ age group } \\
\hline 20 or under years old & 0 & 0 \\
\hline $21-29$ years old & 52 & 13.6 \\
\hline $30-39$ years old & 111 & 28.9 \\
\hline 40-49 years old & 121 & 31.5 \\
\hline 50-59 years old & 93 & 24.2 \\
\hline 60 or older & 7 & 1.8 \\
\hline \multicolumn{3}{|l|}{ Education level } \\
\hline Bachelor Degree & 183 & 47.6 \\
\hline Diploma & 0 & 0 \\
\hline Master Degree & 135 & 35.2 \\
\hline PHD degree & 66 & 17.2 \\
\hline
\end{tabular}

As depicted in Table (4) shows the discussion of the research findings begins with a brief demographic profile of respondents in terms of gender, age, education level, the majority of the respondents were male $(58.3 \%)$, rather than female respondents $(41.7 \%)$. Of this sample, the age bracket of 40 to 49 had the greatest number of respondents (31.5\%), followed by the age bracket of 30 to 39 years old $(28.9 \%)$. and the majority of respondents had completed a bachelor's degree(47.6\%).

\section{Second Section: Travel and General Characteristics:}

As depicted in Figure (4) shows the results of travelled frequency per year, under half $38 \%$ of passengers in Egyptair travelled frequency 3 to 5 per year, while $25 \%$ of passengers travelled frequency 6 to 10 per years, and $23 \%$ of passengers travelled from 1 to 2 times, and $14 \%$ of passengers travelled frequency more than 10 times per years. 


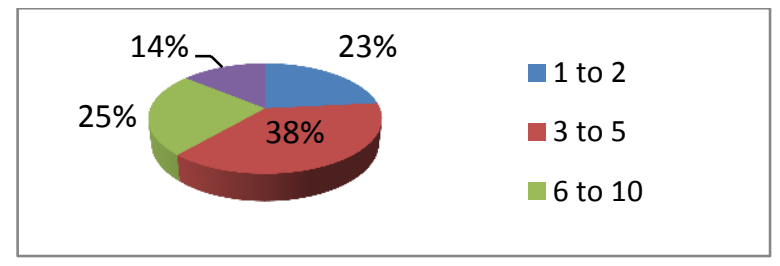

Fig 4: Travel Frequency

Figure (5) describes the general travel purpose for the sample. Firstly, 50.8\% of passengers' of Egyptair travel for Leisure, while $40.1 \%$ of passengers' travel for Business, and $14.1 \%$ of passengers' of Egyptair travel for Personal reasons / Commuting.

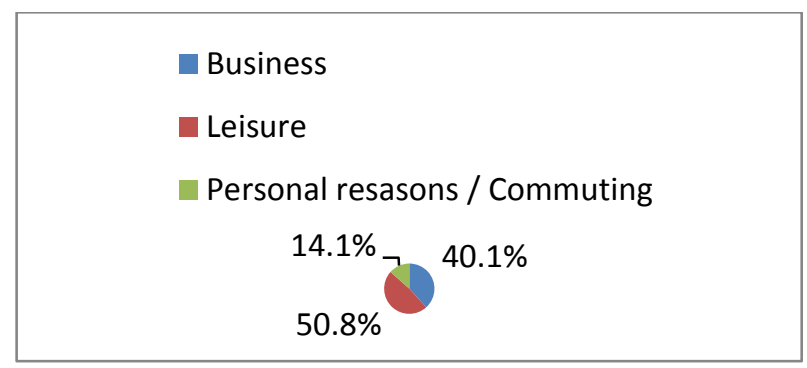

Fig 5: Travel Purpose

Figure (6) shows the results of preferred check- in method, where $41 \%$ of passenger preferred using Mobile / smart phone, while online $33 \%$ of passenger preferred using Online PC, $17 \%$ of passengers in Egyptair used Check-in desk ,and $9 \%$ of passengers in Egyptair used Self - service kiosk.

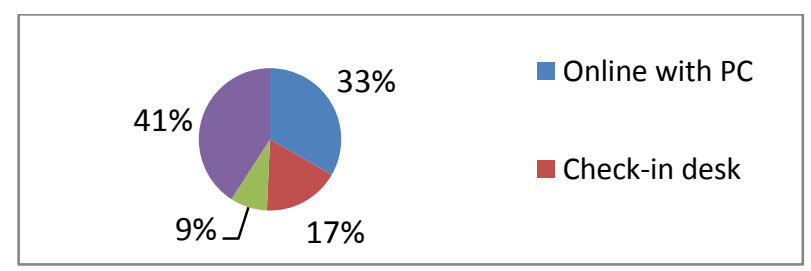

Fig 6: Check- in Method

Figure (7) demonstrates the current mobile usage for the respondents. The most frequently used services by respondents through their mobile devices is airline services (e.g: checkin, booking, buying tickets) 39\%, for social networking 23\%, for banking services $17 \%$, the least used services used by respondents on their mobile devices are entertainment purpose
$12 \%$ and using the mobile for purchasing products $9 \%$.

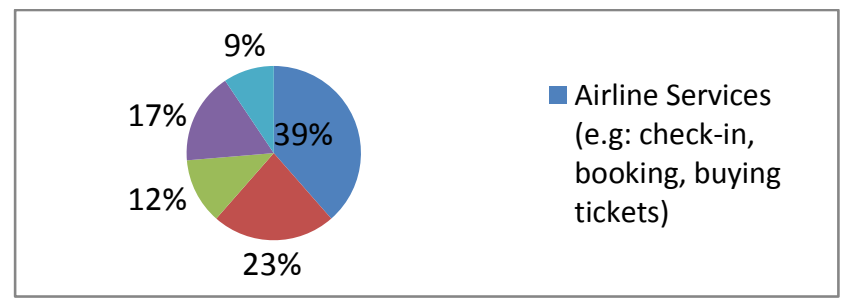

Fig 7: Current use of mobile applications.

\section{The Third Section: Using of Airline Mobile Applications}

Table (5) Using of Airline Mobile Applications

\begin{tabular}{|c|c|c|c|c|c|c|c|}
\hline Variables & $\theta$ & Z & $D$ & $\stackrel{2}{\mathfrak{9}}$ & $\mathscr{\Omega}$ & থ્0 & 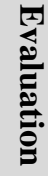 \\
\hline $\begin{array}{l}\text { Application } \\
\text { is easy to use }\end{array}$ & $\underset{\infty}{\infty}$ & $\stackrel{N}{+}$ & $y$ & $\stackrel{\sim}{\infty}_{\infty}^{\sim}$ & 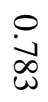 & - & 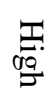 \\
\hline $\begin{array}{l}1 \text { was able to } \\
\text { find the } \\
\text { information } \\
\text { quickly }\end{array}$ & $\stackrel{N}{ \pm}$ & $\vec{i}$ & $\begin{array}{l}\varphi^{\prime} \\
0\end{array}$ & $\stackrel{N}{\omega}_{\omega}^{\sim}$ & $\begin{array}{l}0 \\
\infty \\
\infty \\
\infty\end{array}$ & $\omega$ & $\begin{array}{l}3 \\
\frac{2}{0} \\
\frac{0}{0} \\
\stackrel{0}{0}\end{array}$ \\
\hline $\begin{array}{l}\text { I found the } \\
\text { information } \\
\text { well } \\
\text { organized }\end{array}$ & $\underset{\infty}{\not{\infty}}$ & $\begin{array}{l}\omega \\
\dot{a}\end{array}$ & $\frac{u}{a}$ & $\stackrel{N}{w}$ & $\stackrel{0}{N}$ & $N$ & 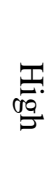 \\
\hline $\begin{array}{c}\text { Steps of } \\
\text { booking } \\
\text { tickets are } \\
\text { straight } \\
\text { forward }\end{array}$ & $\begin{array}{l}\bar{\infty} \\
\dot{N}\end{array}$ & $\underset{+}{\stackrel{\omega}{+}}$ & $\stackrel{\vec{A}}{\vec{A}}$ & $\stackrel{N}{N}$ & $\stackrel{0}{\dot{v}}$ & $\rightarrow$ & $\begin{array}{l}3 \\
3 \\
0 \\
0 \\
0 \\
0 \\
0\end{array}$ \\
\hline
\end{tabular}

Table (5) presents the means and standard deviations of using of airline mobile applications, where the means ranged between (2.38 - 2.29) compared with the total instrument mean for the domain (2.34) the item "Application is easy to use" ranked first with a mean and standard deviation (mean $=2.38$, standard deviation $=0.783$ ) compared with the total instrument mean and the standard deviation. The item "Steps of booking tickets are straight forward" ranked last reached a mean (2.29) and the standard deviation was $(0.757)$ compared with the mean and standard deviation of the total instrument. 
The Fourth Section: Functions of Airline Mobile Applications

Table (6) Functions of Airline Mobile Applications

\begin{tabular}{|c|c|c|c|c|c|c|c|}
\hline Variables & $\mathbf{D}$ & $\mathbf{N}$ & $\mathbf{A}$ & Mean & SD & Rank & Evaluation \\
\hline \multicolumn{8}{|l|}{ Flights } \\
\hline Flight schedule information & 20.1 & 27.1 & 52.9 & 2.33 & 0.789 & 1 & Moderate \\
\hline $\begin{array}{l}\text { Flight status and time table } \\
\text { information }\end{array}$ & 22.9 & 27.6 & 49.5 & 2.30 & 0.710 & 2 & Moderate \\
\hline $\begin{array}{l}\text { Real-time information } \\
\text { of "Favorite" flights }\end{array}$ & 49.2 & 8.9 & 41.9 & 1.93 & 0.953 & 3 & Moderate \\
\hline \multicolumn{8}{|l|}{ Booking } \\
\hline flight booking service & 18.8 & 27.3 & 53.9 & 2.35 & 0.778 & 3 & High \\
\hline Manage booking & 26.8 & 24.7 & 48.4 & 2.22 & 0.841 & 5 & Moderate \\
\hline Mobile Check-in & 18.5 & 23.2 & 58.3 & 2.40 & 0.782 & 2 & High \\
\hline Boarding pass & 25.5 & 31.5 & 43 & 2.17 & 0.810 & 6 & Moderate \\
\hline Baggage information & 15.6 & 18.8 & 65.6 & 2.50 & 0.751 & 1 & High \\
\hline $\begin{array}{l}\text { First \& Business class lounges } \\
\text { information }\end{array}$ & 27.9 & 22.1 & 50 & 2.29 & 0.858 & 4 & Moderate \\
\hline \multicolumn{8}{|l|}{ airport } \\
\hline Airport information & 15.6 & 18.5 & 65.9 & 2.50 & 0.751 & 1 & High \\
\hline Airport services & 37.8 & 22.7 & 39.6 & 2.02 & 0.880 & 3 & Moderate \\
\hline Aiding of passenger activities & 31.5 & 19.5 & 49 & 2.17 & 0.881 & 2 & Moderate \\
\hline \multicolumn{8}{|l|}{ airlines } \\
\hline Special airline service information & 12.2 & 40.1 & 47.7 & 2.35 & 0.692 & 3 & High \\
\hline Actual travel deals and offers & 0 & 41.1 & 58.6 & 2.59 & 0.493 & 2 & High \\
\hline Frequent flyer programs & 0 & 27.6 & 72.4 & 2.72 & 0.448 & 1 & High \\
\hline Destination guide & 17.7 & 32.6 & 49.7 & 2.32 & 0.757 & 4 & Moderate \\
\hline \multicolumn{8}{|l|}{ Ancillary services on mobile devices } \\
\hline $\begin{array}{l}\text { Tourist information (Car rental \& } \\
\text { Hotel booking) }\end{array}$ & 0 & 10.2 & 89.8 & 2.90 & 0.302 & 1 & High \\
\hline Premium seating & 16.7 & 40.6 & 42.7 & 2.26 & 0.726 & 5 & Moderate \\
\hline Premium boarding & 9.9 & 27.6 & 62.5 & 2.53 & 0.670 & 3 & High \\
\hline Pre-purchase meal & 16.1 & 36.2 & 47.7 & 2.32 & 0.735 & 4 & Moderate \\
\hline New and travel alerts & 9.4 & 61.2 & 29.4 & 2.20 & 0.591 & 6 & Moderate \\
\hline On board service information & 7.8 & 14.6 & 77.6 & 2.70 & 0.607 & 2 & High \\
\hline Gallery & 19.3 & 51.3 & 29.4 & 2.10 & 0.691 & 7 & Moderate \\
\hline
\end{tabular}


Table (6) presents the means and standard deviations of flights functions of airline mobile applications, where the means ranged between (2.33- 1.93) compared with the total instrument mean for the field (2.18) the item "Flight schedule information" ranked first with a mean and standard deviation (mean $=2.33$, standard deviation $=0.789$ ) compared with the total instrument mean and the standard deviation. The item "Real-time information of "Favorite" flights" ranked last reached a mean (1.93) and the standard deviation was (0.953) compared with the mean and standard deviation of the total instrument.

Table (6) shows the means and standard deviations of booking functions of airline mobile applications, where the means ranged between (2.50-2.17) compared with the total instrument mean for the domain (2.32) the item "Baggage information" ranked first with a mean and standard deviation (mean $=2.50$, standard deviation $=0.751$ ) compared with the total instrument mean and the standard deviation. The item "Boarding pass" ranked last reached a mean (2.17) and the standard deviation was (0.810) compared with the mean and standard deviation of the total instrument.

Table (6) presents the means and standard deviations of airport functions of airline mobile applications, where the means ranged between (2.50- 2.02) compared with the total instrument mean for the field (2.23) the item "Airport information" ranked first with a mean and standard deviation (mean=2.50, standard deviation $=0.751)$ compared with the total instrument mean and the standard deviation. The item "Airport services" ranked last reached a mean (2.02) and the standard deviation was (0.880) compared with the mean and standard deviation of the total instrument.

Table (6) presents the means and standard deviations of airlines functions of airline mobile applications, where the means ranged between (2.72- 2.32) compared with the total instrument mean for the domain (2.50) the item "Frequent flyer programs" ranked first with a mean and standard deviation (mean $=2.72$, standard deviation $=0.448$ ) compared with the total instrument mean and the standard deviation. The item "Destination guide" ranked last reached a mean (2.32) and the standard deviation was (0.757) compared with the mean and standard deviation of the total instrument.

Table (6) presents the means and standard deviations of ancillary services on mobile devices functions of airline mobile applications, where the means ranged between (2.90- 2.10) compared with the total instrument mean for the field (2.43) the item "Tourist information (Car rental \& Hotel booking)" ranked first with a mean and standard deviation (Mean=2.90, standard deviation $=0.302$ ) compared with the total instrument mean and the standard deviation. The item "Gallery" ranked last reached a mean (2.10) and the standard deviation was (0.691) compared with the mean and standard deviation of the total instrument.

\section{The Fifth Section: Traveller Requirements}

Table (7) Innovative Features / Services

\begin{tabular}{l|c|c|c|c|c|c|c}
\hline \multicolumn{1}{c|}{ Variables } & D & N & A & Mean & SD & Rank & Evaluation \\
\hline $\begin{array}{l}\text { Real time update on flights } \\
\text { status on mobile }\end{array}$ & 20.3 & 35.4 & 44.3 & 2.32 & 0.735 & 8 & Moderate \\
\hline $\begin{array}{l}\text { Real time baggage arrival } \\
\text { update on mobile }\end{array}$ & 22.4 & 19.3 & 58.3 & 2.36 & 0.825 & 7 & High \\
\hline Calendar display & 36.5 & 14.3 & 49.2 & 2.13 & 0.918 & 9 & Moderate \\
\hline Use mobile onboard & 6 & 39.3 & 54.7 & 2.49 & 0.609 & 6 & High \\
\hline Receive directions on mobile & 26.8 & 36.2 & 37 & 2.10 & 0.793 & 10 & Moderate \\
\hline $\begin{array}{l}\text { Use mobile for booking, } \\
\text { check-in, etc. }\end{array}$ & 4.4 & 22.1 & 73.4 & 2.69 & 0.561 & 3 & High \\
\hline Self-luggage tagging & 0 & 40.9 & 59.1 & 2.59 & 0.492 & 4 & High \\
\hline $\begin{array}{l}\text { Airport kiosks to buy } \\
\text { additional services for extra }\end{array}$ & 0 & 26.8 & 73.2 & 2.73 & 0.444 & 2 & High \\
\hline $\begin{array}{l}\text { Pay in advance for } \\
\text { services flyer }\end{array}$ & 0 & 16.7 & 83.3 & 2.83 & 0.373 & 1 & High \\
\hline $\begin{array}{l}\text { Dynamic frequent } \\
\text { programs profile }\end{array}$ & & & & & & High
\end{tabular}


Table (7) presents the means and standard deviations of traveller requirements (Innovative features / services), where the means ranged between (2.83- 2.10) compared with the total instrument mean for the field (2.48) the item "Dynamic frequent flyer programs profile" ranked first with a mean and standard deviation (mean=2.83, standard deviation $=0.373$ ) compared with the total instrument mean and the standard deviation. The item "Receive directions on mobile" ranked last reached a mean (2.10) and the standard deviation was (0.793) compared with the mean and standard deviation of the total instrument.

Table (8) Airlines Travel Experience

\begin{tabular}{l|c|c|c|c|c|c|c|}
\hline \multicolumn{1}{c|}{ Variables } & D & N & A & Mean & SD & Rank & Evaluation \\
\hline Disruption management & 22.1 & 27.9 & 50 & 2.28 & 0.803 & 9 & Moderate \\
\hline Check.in/ Baggage process & 3 & 7 & 92.7 & 2.92 & 0.247 & 1 & High \\
\hline Seating & 2.1 & 24.2 & 73.7 & 2.72 & 0.496 & 3 & High \\
\hline Make changes to booking & 4.4 & 22.4 & 73.2 & 2.69 & 0.552 & 4 & High \\
\hline In-flight service & 17.7 & 18.2 & 64.1 & 2.46 & 0.777 & 6 & High \\
\hline Baggage claim at destination & 0 & 18.8 & 81.3 & 2.81 & 0.391 & 2 & High \\
\hline Optional service fees & 13.3 & 39.6 & 47.1 & 2.34 & 0.701 & 8 & High \\
\hline Boarding / De boarding & 17.7 & 37.8 & 44.5 & 2.27 & 0.743 & 10 & Moderate \\
\hline Choosing \& booking flight & 0 & 54.9 & 45.1 & 2.45 & 0.496 & 7 & High \\
\hline Flight crew experience & 8 & 37.8 & 61.5 & 2.61 & 0.505 & 5 & High \\
\hline
\end{tabular}

Table (8) presents the means and standard deviations of traveller requirements (aspects of airlines travel experience could be improved), where the means ranged between (2.92- 2.27) compared with the total instrument mean for the field (2.56) the item "Check-in / Baggage process" ranked first with a mean and standard deviation $($ mean $=2.92$, standard deviation $=$ 0.247) compared with the total instrument mean and the standard deviation. The item "Boarding / De boarding" ranked last reached a mean (2.27) and the standard deviation was (0.743) compared with the mean and standard deviation of the total instrument.

\section{The Sixth Section: Cross- Selling}

Table (9) Cross Selling

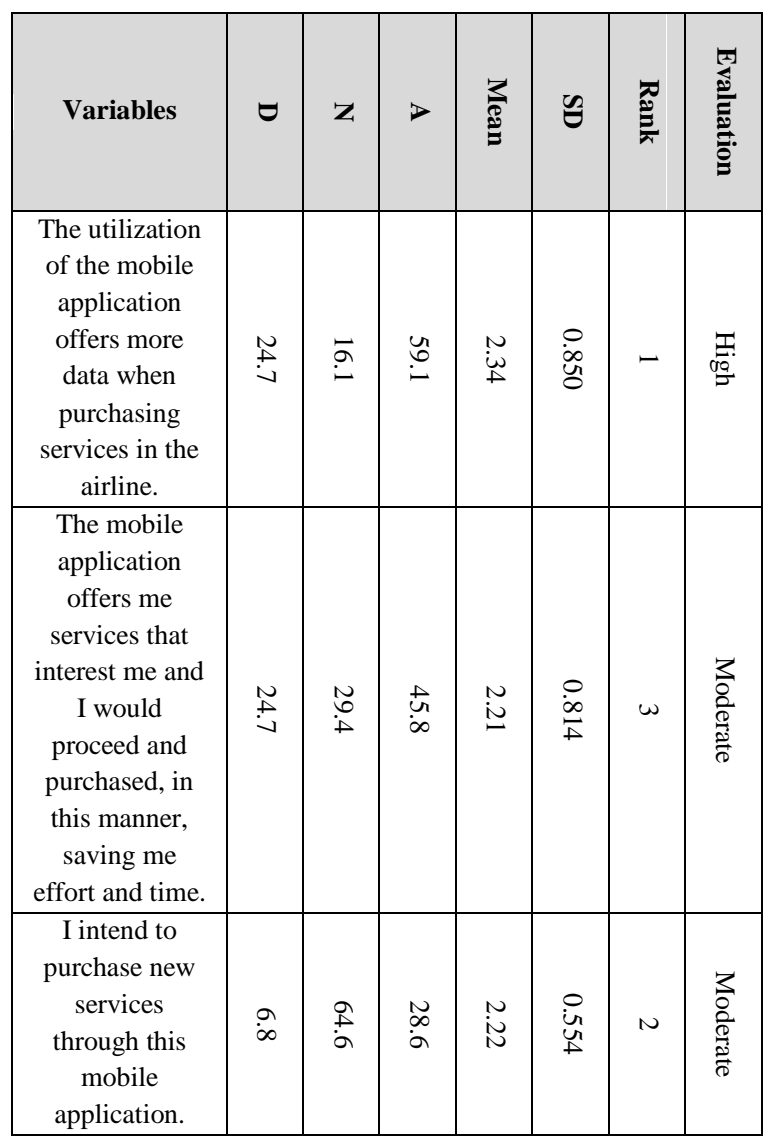

Table (9) presents the means and standard deviations of cross- selling, where the means ranged between (2.34- 2.21) compared with the total instrument mean for the field (2.26) the item "The utilization of the mobile application offers more data when purchasing services in the airline" ranked first with a mean and standard deviation (mean $=2.34$, standard deviation $=0.850$ ) compared with the total instrument mean and the standard deviation. The item "The mobile application offers me services that interest me and I would proceed and purchased, in this manner, saving me effort and time" ranked last reached a mean (2.21) and the standard deviation was (0.814) compared with the mean and standard deviation of the total instrument. 


\section{The Seventh Section: Image Perception}

Table (10) Image Perception

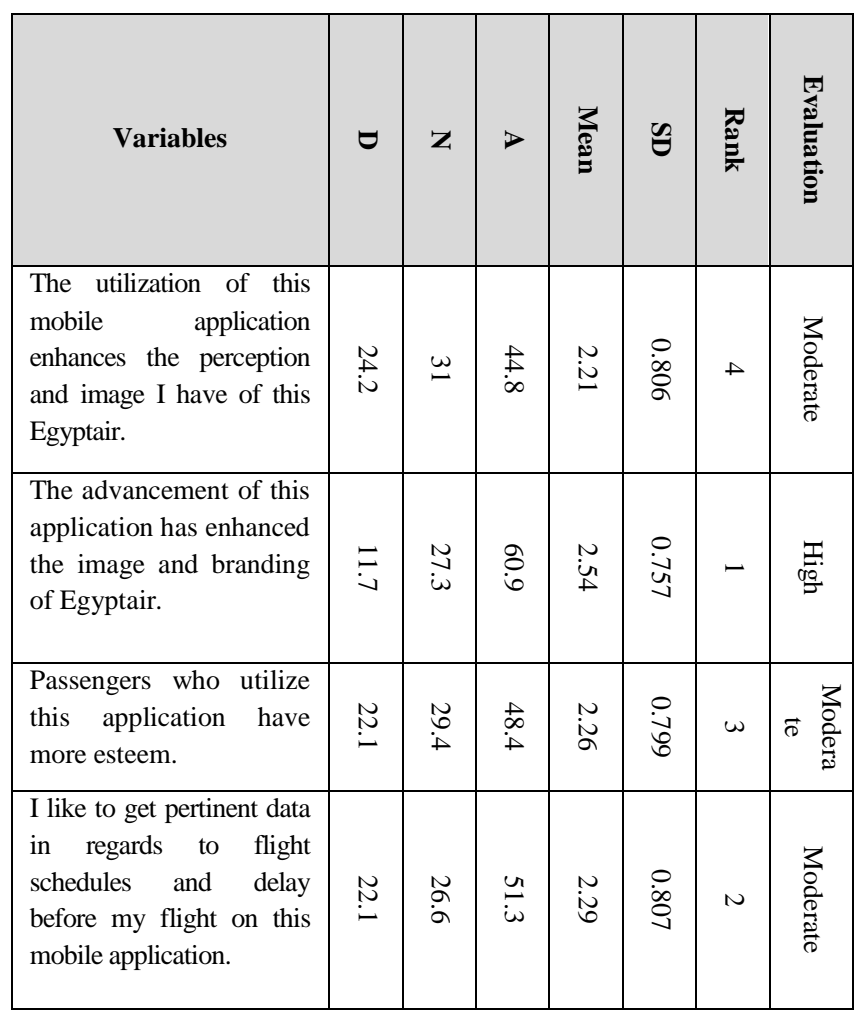

Table (10) presents the means and standard deviations of image perception, where the means ranged between (2.54- 2.21) compared with the total instrument mean for the field (2.33) the item "The advancement of this application has enhanced the image and branding of Egyptair" ranked first with a mean and standard deviation (mean $=2.54$, standard deviation $=0.757)$ compared with the total instrument mean and the standard deviation. The item "The utilization of this mobile application enhances the perception and image I have of this Egyptair" ranked last reached a mean (2.21) and the standard deviation was (0.806) compared with the mean and standard deviation of the total instrument.

\section{The Eighth Section: Passenger Satisfaction}

Table (11) Passenger Satisfaction

\begin{tabular}{|c|c|c|c|c|c|c|c|}
\hline Variables & $\theta$ & $\mathbf{Z}$ & $D$ & 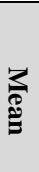 & $\mathscr{\sigma}$ & 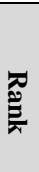 & 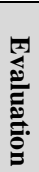 \\
\hline $\begin{array}{l}\text { In general, I am } \\
\text { satisfied with the } \\
\text { service I obtained } \\
\text { from this application. }\end{array}$ & $\stackrel{N}{N}$ & $\begin{array}{l}N \\
\dot{a}\end{array}$ & $\underset{\omega}{\stackrel{u}{o}}$ & $\underset{N}{N}$ & 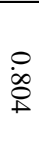 & $N$ & $\frac{3}{\frac{3}{8}}$ \\
\hline $\begin{array}{l}\text { I have a pleasant } \\
\text { feeling while utilizing } \\
\text { this application. }\end{array}$ & $\underset{\sim}{\omega}$ & $\begin{array}{l}n \\
\alpha\end{array}$ & $\stackrel{\vec{b}}{\sim}$ & $\begin{array}{l}N \\
N\end{array}$ & $\underset{\infty}{\stackrel{\infty}{\sim}}$ & $\triangle$ & $\frac{3}{\frac{3}{0}}$ \\
\hline $\begin{array}{l}\text { The utilization of this } \\
\text { mobile application has } \\
\text { been a good } \\
\text { experience. }\end{array}$ & $\stackrel{N}{N}$ & $\begin{array}{l}\text { U } \\
\text { in }\end{array}$ & $\underset{\infty}{+\infty}$ & $\stackrel{N}{N}$ & 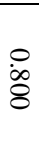 & $\omega$ & $\frac{3}{\frac{3}{0}}$ \\
\hline $\begin{array}{l}\text { In general, I am } \\
\text { satisfied with the } \\
\text { process in which the } \\
\text { data and services of } \\
\text { the airline have been } \\
\text { managed through this } \\
\text { mobile application. }\end{array}$ & $\stackrel{N}{N}$ & $\begin{array}{l}N \\
\alpha\end{array}$ & $\underset{i}{\tilde{\omega}}$ & $\stackrel{N}{i}$ & 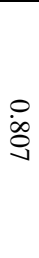 & - & $\begin{array}{l}\frac{3}{0} \\
\frac{2}{2} \\
\frac{0}{2} \\
\stackrel{0}{0}\end{array}$ \\
\hline
\end{tabular}

Table (11) presents the means and standard deviations of passenger satisfaction, where the means ranged between (2.29- 2.26) compared with the total instrument mean for the domain (2.28) the item "In general, I am satisfied with the process in which the data and services of the airline have been managed through this mobile application" ranked first with a mean and standard deviation (mean $=2.29$, standard deviation $=0.807$ ) compared with the total instrument mean and the standard deviation. The item "I have a pleasant feeling while utilizing this application" ranked last reached a mean (2.26) and the standard deviation was (0.817) compared with the mean and standard deviation of the total instrument. 


\section{The Ninth Section: Security Control}

Table (12) Security Control

\begin{tabular}{|c|c|c|c|c|c|c|}
\hline Variables & $\theta$ & $\mathbf{z}$ & $>$ & 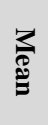 & $\mathscr{\theta}$ & 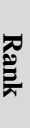 \\
\hline $\begin{array}{l}\text { I think I will trust this mobile } \\
\text { application. }\end{array}$ & $\stackrel{N}{N}$ & $\begin{array}{l}\text { U } \\
\text { in }\end{array}$ & $\stackrel{\vec{\infty}}{-\vec{v}}$ & $\stackrel{N}{N}$ & $\stackrel{0}{\infty}$ & $u$ \\
\hline $\begin{array}{l}\text { This mobile app is concern with the } \\
\text { attentiveness of its passengers. }\end{array}$ & $\stackrel{N}{N}$ & u & $\underset{N}{\tilde{U}}$ & $\stackrel{\sim}{\omega}$ & $\stackrel{\infty}{\infty}$ & N \\
\hline $\begin{array}{l}\text { At the point when this application } \\
\text { structures its business offer; it } \\
\text { considers the wants and needs of its } \\
\text { passengers. }\end{array}$ & $\stackrel{N}{N}$ & $\begin{array}{l}N \\
\sigma\end{array}$ & In & $\underset{\infty}{N}$ & $\begin{array}{l}\circ \\
\dot{\infty} \\
\stackrel{\infty}{\infty}\end{array}$ & $\phi$ \\
\hline $\begin{array}{l}\text { This mobile application provides } \\
\text { real information. }\end{array}$ & $\underset{\omega}{N}$ & $\begin{array}{l}\text { un } \\
\text { in }\end{array}$ & ur & 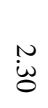 & $\stackrel{\infty}{\infty}$ & $\omega$ \\
\hline $\begin{array}{l}\text { I am satisfied to utilize this this } \\
\text { mobile application given that it } \\
\text { supply me security, and control of } \\
\text { my time within the airline. }\end{array}$ & $\ddot{\omega}$ & $\underset{\text { in }}{w}$ & Uొ & $\tilde{N}_{2}$ & i & - \\
\hline $\begin{array}{l}\text { When the security control region is } \\
\text { past and in the boarding area, being } \\
\text { informed by the mobile application } \\
\text { gives me harmony }\end{array}$ & $\stackrel{N}{\sim}$ & 崩 & $\begin{array}{l}\underset{\varpi}{\infty} \\
\infty\end{array}$ & $\stackrel{\sim}{\omega}$ & 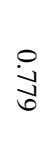 & $a$ \\
\hline
\end{tabular}

Table (12) presents the means and standard deviations of security control, where the means ranged between (2.56- 2.13) compared with the total instrument mean for the domain (2.31) the item "I am satisfied to utilize this this mobile application given that it supply me security, and control of my time within the airline" ranked first with a mean and standard deviation $($ Mean $=2.56$, standard deviation $=$ 0.516) compared with the total instrument mean and the standard deviation. The item "When the security control region is past and in the boarding area, being informed by the mobile application gives me harmony" ranked last reached a mean (2.13) and the standard deviation was (0.779) compared with the mean and standard deviation of the total instrument.

\subsection{Spearman Correlation analyses}

Table (13) Correlation between Passenger Satisfaction and Using of Airline Mobile Applications

\begin{tabular}{|l|c|c|}
\hline \multicolumn{2}{|c|}{} & $\begin{array}{c}\text { Using of Airline } \\
\text { Mobile } \\
\text { Application }\end{array}$ \\
\hline $\begin{array}{l}\text { Passenger } \\
\text { Satisfaction }\end{array}$ & $\begin{array}{c}\text { Correlation } \\
\text { Coefficient }\end{array}$ & $.717^{* *}$ \\
\cline { 2 - 3 } & Sig. & .000 \\
\hline
\end{tabular}

As seen in the table (13), there is a positive and significant relationship between passenger satisfaction and using of airline mobile applications. The value of spearman correlation coefficient was $\left(.717^{* *}-\operatorname{sig}=\right.$ $0.000)$. These results showed that there is a strong positive relation between passenger satisfaction and using of airline mobile applications. This positive correlation indicates that as the passenger satisfaction increases, using of airline mobile applications increases.

Table (14) Correlation between Functions of Egyptair Mobile Application and Passenger Satisfaction

\begin{tabular}{|l|c|c|}
\hline \multicolumn{2}{|c|}{} & \multicolumn{1}{c|}{$\begin{array}{c}\text { Passenger } \\
\text { Satisfaction }\end{array}$} \\
\hline $\begin{array}{l}\text { Functions of } \\
\text { Egyptair } \\
\text { Mobile } \\
\text { Application }\end{array}$ & $\begin{array}{l}\text { Correlation } \\
\text { Coefficient }\end{array}$ & $.968^{* *}$ \\
\cline { 2 - 3 } & Sig. & .000 \\
\hline
\end{tabular}

As seen in the table (14), there is a positive and significant relationship between functions of Egyptair mobile application and passenger satisfaction. The value of spearman correlation coefficient was $\left(.968^{* *}-\operatorname{sig}=0.000\right)$. These results showed that there is very strong positive relation between functions of Egyptair mobile application and passenger satisfaction. 
This positive correlation indicates that as the functions of Egyptair mobile application increases, passenger satisfaction increases.

Table (15) Correlation between Security Control and Passenger Satisfaction

\begin{tabular}{|l|l|c|}
\hline \multicolumn{2}{|c|}{} & $\begin{array}{c}\text { Passenger } \\
\text { Satisfaction }\end{array}$ \\
\hline $\begin{array}{l}\text { Security } \\
\text { Control }\end{array}$ & $\begin{array}{l}\text { Correlation } \\
\text { Coefficient }\end{array}$ & $.868^{* *}$ \\
\cline { 2 - 3 } & Sig. & .000 \\
\hline
\end{tabular}

As seen in the table (15), there is a positive and significant relationship between security control and passenger satisfaction. The value of spearman correlation coefficient was $\left(.868^{* *}\right.$ - sig $=0.000)$. These results showed that there is very strong positive relation between security control and passenger satisfaction. This positive correlation indicates that as security control increases, passenger satisfaction increases.

Table (16) Correlation between Image Perception and Using of Airline Mobile Applications

\begin{tabular}{|l|c|c|}
\hline \multicolumn{2}{|c|}{} & $\begin{array}{l}\text { Using of Airline } \\
\text { Mobile } \\
\text { Applications }\end{array}$ \\
\hline $\begin{array}{l}\text { Image } \\
\text { Perception }\end{array}$ & $\begin{array}{c}\text { Correlation } \\
\text { Coefficient }\end{array}$ & $.756^{* *}$ \\
\cline { 2 - 3 } & Sig. & .000 \\
\hline
\end{tabular}

As seen in the table (16), there is a positive and significant relationship between image perception and using of airline mobile applications. The value of spearman correlation coefficient was $\left(.717^{* *}-\operatorname{sig}=\right.$ 0.000). These results showed that there is a strong positive relation between image perception and using of airline mobile applications. This positive correlation indicates that as the image perception increases, using of airline mobile applications increases.
Table (17) Correlation between Security Control and Image Perception

\begin{tabular}{|l|l|c|}
\hline \multicolumn{2}{|c|}{} & Image Perception \\
\hline $\begin{array}{l}\text { Security } \\
\text { Control }\end{array}$ & $\begin{array}{l}\text { Correlation } \\
\text { Coefficient }\end{array}$ & $.799^{* *}$ \\
\cline { 2 - 3 } & Sig. & .000 \\
\hline
\end{tabular}

As seen in the table (17), there is a positive and significant relationship between security control and image perception. The value of spearman correlation coefficient was $\left(.799^{* *}\right.$ $\operatorname{sig}=0.000$ ). These results showed that there is strong positive relation between security control and image perception. This positive correlation indicates that as security control increases, image perception increases.

\subsection{Regression analysis:}

Table (18) Simple Linear Regression analysis

\begin{tabular}{|c|c|c|c|c|}
\hline & 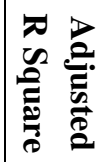 & x & $\frac{\mathscr{s}}{x}$ & 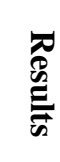 \\
\hline $\begin{array}{l}\text { Impact of passenger } \\
\text { satisfaction on } \\
\text { using of airline } \\
\text { mobile applications }\end{array}$ & 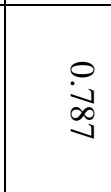 & 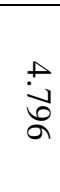 & $\stackrel{8}{8}$ & $\frac{8}{8}$ \\
\hline $\begin{array}{l}\text { Impact of functions } \\
\text { of Egyptair mobile } \\
\text { applications on } \\
\text { passenger } \\
\text { satisfaction }\end{array}$ & $\begin{array}{l}\stackrel{0}{\circ} \\
\stackrel{\Delta}{*}\end{array}$ & 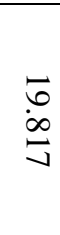 & $\stackrel{8}{8}$ & $\frac{8}{2}$ \\
\hline $\begin{array}{lr}\text { Impact of } & \text { security } \\
\text { control } & \text { on } \\
\text { passenger } & \\
\text { satisfaction } & \end{array}$ & $\begin{array}{l}0 \\
\dot{\infty} \\
9\end{array}$ & $\begin{array}{l}\stackrel{+}{+} \\
\stackrel{+}{0}\end{array}$ & $\stackrel{8}{8}$ & 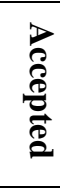 \\
\hline $\begin{array}{l}\text { Impact of image } \\
\text { perception on using } \\
\text { of airline mobile } \\
\text { applications }\end{array}$ & $\stackrel{\circ}{\ddot{\alpha}}$ & 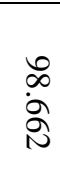 & $\dot{8}$ & $\frac{2}{8}$ \\
\hline $\begin{array}{l}\text { Impact of security } \\
\text { control on image } \\
\text { perception }\end{array}$ & $\underset{\infty}{\stackrel{0}{\infty}}$ & $\begin{array}{l}+ \\
\stackrel{\infty}{8} \\
\stackrel{N}{8}\end{array}$ & $\stackrel{8}{8}$ & $\begin{array}{l}\frac{1}{8} \\
\frac{8}{2} \\
\frac{8}{2}\end{array}$ \\
\hline
\end{tabular}


From results in table (18), passenger satisfaction affects increasing using of mobile airline applications by $78.8 \%$ Moreover, The results of Simple linear regression analysis shows that functions of Egyptair mobile applications affects passenger satisfaction with $94.7 \%$, then security control affects passenger satisfaction with $86.7 \%$, image perception affects using of airline mobile applications with $76.6 \%$, and finally security control affects image perception with $71.8 \%$.

\section{Summary and Conclusion}

This research aims to investigate the characteristics in Egyptair passengers in terms of acceptance new technologies; specifically the mobile services in airline, which are provided by the Egyptair, this research analyze the effects of mobile marketing tool at passenger satisfaction of Egyptair. Different tests were applied, including reliability test, correlation test, and regression test. The following results were obtained.

- The findings from the distributed questionnaires revealed that $50.3 \%$ of passengers in Egyptair are satisfied with mobile service, with mean rating 2.28 out of 3 on a Likert scale.

- In terms of gender, were male (58.3) have a greater intention to use airline mobile services than female.

- In term of age, the age groups 40-49 years and 30-39 years are more in favours of using the service than 20 or under years old.

- The application is very flexible and dynamic in nature. Airline mobile applications are the best way of airline reservation because of its ease of use and availability when needed; there is positive significant relationship between passenger satisfaction and using of airline mobile application. The value of spearman correlation coefficient was $(.717 * *-\mathrm{sig}=0.000)$.

- Results showed that there is very strong positive relation between functions of Egyptair mobile application and passenger satisfaction. The value of spearman correlation coefficient was $\left(.968^{* *}-\operatorname{sig}=0.000\right)$

- Results showed that there is very strong positive relation between security control and passenger satisfaction. The value of spearman correlation coefficient was $\left(.868^{* *}-\mathrm{sig}\right.$ $=0.000)$.

\section{Recommendations}

1. Egyptair should develop airline mobile applications to offer airline service. They should announce their airline mobile applications in their website, social media. They should make training for their staff in mobile applications using. Developing airline mobile applications include several features that increase the number of passengers and attract others to use it.

2. Egyptair must invest in next-generation technology that automates manual tasks, shares information and provides proactive communication to the passenger. This will transform the overall passenger expertise and make dynamic enhancements in operations.

3. Egyptair should be aware of rising technologies that might facilitate improve their daily operations and therefore the satisfaction of their passengers.

4. Egyptair should additionally adapt to new trends that are rapidly growing in the world for example airline mobile technologies. A better expertise would help retain more passengers and additionally presumably herald new 
passengers as these options make the airline or airport stand out among the competition.

5. Egyptair need to constantly match technology and passenger needs to sustain a competitive advantage.

6. Egyptair will use airline mobile application to provide better service to passengers at variety touch points along the trip, delivering real-time, relevant, and value-added information, offers, discounts, and personalized services that support build a trusted relationship

7. Egyptair will recognize the dynamical requirements and expectations of passengers' Egyptair; hence, passenger surveys ought to be sporadically conducted to generate three types of service performance reports.

\section{References}

1. Alkaya, A. (2007). "Marketing Communication Process Through Mobile Channels and A Research on University Students' Attitudes Towards Mobile Marketing”, Unpublished Master's Thesis, Anadolu University Institute of Social Sciences.

2. Alo O.O., Adeyanju I.A, Muritala A.A., Olabiyisi S.O. and Omidiora E.O. (2014), "DEVELOPMENT OF A MOBILE AIRLINE RESERVATION APPLICATION", Department of Computer Science and Engineering, Ladoke Akintola University of Technology, Ogbomoso, Oyo State, Nigeria.

3. Amadeus (2011). "The always connected traveler: How mobile will transform the future of air travel", Available online at: http://www.amadeus.com/airlineit/the-alwaysconnected-traveller/, (accessed 21 June 2018).

4. Ary, D., Jacobs, L. and Razavieh, A. (2002). "Introduction to Research in Education", Belmont, CA: Wadsworth/Thomson.

5. Barnes, S. (2003). "M business: the strategic implications of mobile communications". Routledge.
6. Barutçu, S., \& Öztürk Göl, M. (2009). “Attitudes Towards Mobile Ads and Mobile Advertising Tools", KMU Journal of Economics and Administrative Sciences (17).

7. Budiu, R.(2013). "Mobile: Native Apps, Web Apps, and Hybrid Apps", available online at: https://www.nngroup.com/articles/Mobilenative-Apps/, (accessed 28 August 2018).

8. Buhalis, D. (2004). "E-Airlines: strategic and tactical use of ICTs in the airline industry". Information and Management, 41, 805-825.

9. Delhumeau, H. (2013). "Mobile Apps: actors and business model review", Available Online at:

https://hdelhumeau.wordpress.com/2013/03/09 /Mobile-Appss-actors-business-model-review/, (Accessed 25 august 2018).

10. Dickinger, A., Haghiran, P., Murphy, J., \& Scharl, A. (2004). "An investigation and conceptual modelo SMS marketing", $38^{\text {th }}$ Hawaii International Conference on System Sciences (HICSS-38).

11. Döckel, A. (2003). "The Effect of Retention Factors on Organizational Commitment: An Investigation of High Technology Employees", Master Thesis, Faculty of Economics and Management Sciences, University of Pretoria.

12. Egyptair (2017). "Egyptair annual report 2016/2017", available online at: https://www.egyptair.com, (accessed 28 may 2018).

13. Egyptair (2018). "Egyptair mobile application", available online at: https://play.google.com/store/apps/details?id=c om.linkdev.egyptair.app\&hl=en, (accessed 28 may 2018).

14. Ekelhart H.A., Manhoot G.B. (2008). "XML Security - a Comparative Literature Review", Journal of System and Software, Vol.81, No.10, pp715-724.

15. Florido-Benítez, L., Del Alcázar, B., \& González, E. (2014b). "The implementation of mobile applications in airports to increase levels of passenger satisfaction", $1^{\text {st }}$ IMAT International Tourism Marketing Symposium, Valencia, Spain.

16. Hermoso de Mendoza, C. (2004). "Mobile, new ways to communication”. IPMARK, 616, 30-34.

17. Howard, L., Amir, F., Shaun, K. (2010). "Airline of the Future: Smart Mobility Strategies that Will Transform the Industry", 
Cisco Internet Business Solutions Group (IBSG), Unite State.

18. Kaplan, M. (2012). "If you love something, let it go mobile: Mobile marketing and mobile social media 4x. Business Horizons", 55(2), 129-139.

http://dx.doi.org/10.1016/j.bushor.2011.10.009.

19. Karaca, Ş., \& Gülmez, M. (2010). "Mobile Marketing: A Conceptual Evaluation”. Journal of Academic Approaches, 1 (1), 69-81.

20. Kennedy,E.H \& Gretzel, U. (2012). "A Taxonomy of Mobile Apps In Tourism”, EReview of tourism Research (eRTR), Vol. 10,No.2, Pp. 47-50.

21. Kim, H., Chan, C.H., Gupta, S., (2005). "Valuebased adoption of mobile internet: an empirical investigation", Decision Support Systems 43, PP. 111-126.

22. Lubbe, B., Louw, L. (2010). "The perceived value of mobile devices to passengers across the airline travel activity chain". Journal of Air Transport Management, 16, PP. 12-15.

23. Martín de Bernardo, C., \& Priede, T. (2007). "Marketing $\mathrm{M}$ vil: A new communication tool”, (pp. 30). La Coruña: Netbiblo.

24. Melendo, L. (2010). "Mobile phone contributions to marketing", Situation and uses in Spain in 2009. (Unprecedented thesis of master's degree). European University of Madrid.

25. NIIT Technologies (2018). "mobility in airlines", Available online at: http:// http://www.niit-tech.com, (accessed 21 may 2018).

26. Mobile Marketing Association (2009). "Mobile marketing", Available online at: http://www.mmaspain.com/index.htm (accessed 21 may 2018).

27. Norm, R. (2011). "Mobile Marketing: How are consumers reacting?". PhoCusWright Innovation Edition, 1-8.

28. Nunnally, J. (1978). "Psychometric Theory", McGraw-Hill, New York.

29. Pagiavlas, N., Stratmann, E., Marburger, M., Young, S. (2005). "MOBILE BUSINESS COMPREHENSIVE MARKETING STRATEGIES OR MERELY IT EXPENSES? A CASE STUDY OF THE US AIRLINE INDUSTRY", Journal of Electronic Commerce Research, VOL. 6, NO.3.

30. Scharl,A, Dickinger,A, and ,Murphy,J.(2005). "diffusion and success factors of mobile marketing, electronic commerce research and applications",4,pp.159-173.

31. Sigala, M. (2001). "Modelling E-Marketing Strategie: Internet Presence and exploitation of Greek Hotels". Journal of Travel \& Tourism Marketing, 11, 83-103. http://dx.doi.org/10.1300/J073v11n02_05.

32. Shankar, V., \& Balasubramanian, S. (2009). "Mobile Marketing: A Synthesis and Prognosis. Journal of Interactive Marketing", 23(2),

118-129. http://dx.doi.org/10.1016/j.intmar.2009.02.002.

33. SITA (2009). "Airline IT trend survey". Available online at: http://www.sita.aero/content/airline-ittrends-survey-2009 (Accessed 20August 2018).

34. Vlachos, P., \& Vrechopoulos, A. (2007). "Mobile Marketing - Achieving Competitive Advantage through Wireless Technology", Journal of Services Marketing, 21(7). 